\title{
Article
}

\section{BOUND BY INFINITIES: TECHNOLOGY, IMMEDIACY AND OUR ENVIRONMENTAL CRISIS*}

\author{
Michael L. Melmed ${ }^{1}$
}

\begin{abstract}
This paper explores the relationship between human desire, technology, and imagination, emphasizing (1) the phenomenology of this relationship, and (2) its ontological and ecological ramifications. Drawing on the work of Bion and Winnicott, the paper will develop a psychoanalytic container for attitudes contributing to our current climate-based crisis, paying special attention to the problematic effect technology has had on our sense of time and place. Many of our technologies stunt sensuous engagement, collapse psychic space, diminish our capacity to tolerate frustration, and blind us to our dependence on worlds beyond the human. In short, our technologies trouble our relationship to our bodies and other bodies. The paper argues that omnipotent fantasies organizing our relationship to technology, to each other, and to the nonhuman world, have cocooned us in a kind of virtual reality that devastates a sense of deep obligation to the environment.
\end{abstract}

KEY WORDS: omnipotent fantasy; technology; Bion; Winnicott; the body; climate crisis; Covid-19

https://doi.org/10.1057/s11231-020-09258-8

O God, I could be bounded in a nutshell and count myself a king of infinite space,

were it not that I have bad dreams.

Hamlet, II:2

Life is built up and broken down by many tendencies that counter, fuse and split, amplifying this here, and muting that there. One obvious fact of life is that it is always mediated by more life. Nothing exists in isolation. Oddly,

Michael L. Melmed, Psy. D., clinical psychologist and Assistant Professor, supervisor, Department of Psychiatry, Columbia University. Psychoanalytic candidate, NYU Postdoctoral Program in Psychotherapy and Psychoanalysis; in private practice in Lower Manhattan.

Address Correspondence to: Michael L. Melmed, Psy. D., 29 Fifth Avenue Suite 1B, New York, NY, 10003, USA. Email: melmed.michael@gmail.com

*A version of this paper was presented to the Association for the Psychoanalysis of Culture \& Society, Rutgers, N.J., on October, 25th, 2019. 
though, life also has a tendency to be immediated, to bypass itself so it can both go on being and become something new. A simple example of this is the way in which a chick will hatch from its egg (Melmed, 2018). It does so using an egg-tooth, a tool of sorts the chick soon outgrows and discards after emerging. Mediating and immediating tendencies in ways oppose, and in ways reciprocally presuppose each other. There are elements of each inextricably woven into the other, moving in a continual teeter-totter throughout life. I posit that certain attitudes in our culture have emerged from and congealed around life's immediating tendency and-to great destructive effect, especially in times like ours-have organized into a cult of immediacy.

The stirrings of such attitudes may be traced back to the advent of human technology, which in a very general sense is the extension or amplification of our capacities and their function in the environment. We often speak of technology as being invented by us, but it is also technology that invents and reinvents us at the most basic level, reshaping our relationship to time and place. Early tools were used to probe, open, and access areas of the world, generating events otherwise impossible, or requiring tremendous levels of effort. One can watch a video of a chimpanzee using specialized stones as hammer and anvil to crush the casing and access the flesh of a nut while a young chimp watches, rapt (BBC Studios, 2008). In such an act, and countless others, worlds of possibilities are born. Caloric, aesthetic, gastronomical, procreative, pedagogical, cultural, ecstatic, affective, and sensuous realities begin to seed, germinate, effectuate.

Our sense of time and place is based, in part, on the rate of fluctuation of our desire and satisfaction and, vice versa, varieties of desire and satisfaction are shaped by our relationship to, and sense of, time and place. An ancient, though increasingly obsolete, measure of the flux of time and terrain (i.e., place) has been the cycle of seasons, the synchronous waxing and waning of spiritual and material needs and desires, and the activities that contribute to and satisfy these. Technologies influence this natural synchrony, introducing new rhythms and textures. In our age, they have tended to hyper-accentuate an ever-accelerating leapfrogging of desire and satisfaction. Fast-forward to our cellphones, for example, and look at how many functions have been condensed into and flattened by them, cocooned by the screen.

The ultimate medium of our experience, place-time, has been, by virtue of our technologies increasingly immediated: mined, drilled, bulldozed, dislocated, discarded, sold and, nowadays, distilled into apps-and all quite invisibly to the consumer. Silvia Federici (2018) cites data that one computer requires on average 17 tons of materials and thirty-three thousand 
liters of pure water, taken from the natural commonwealth of far-away lands. Winnicott (1945) speaks to the extreme prevalence of the defense mechanism of dissociation, calling urban life itself a serious dissociation for civilization. He speaks to the importance of a child enjoying "a ruthless relation to his mother, mostly showing in play, and... [that] without this play with her he can only hide a ruthless self" fed through dissociated acts of destruction (p. 142). I would argue that our culture qua mother-split-off as it is from an experience of the natural world and its rhythms-does not tolerate or include the ruthless aspects of life, which in traditional cultures is contained (in the Bionian sense) and expressed in the serious play of ritual (Melmed \& Santiago, 2019). Such ritual cultivates the capacity to surrender (Ghent, 1990) oneself to, and to practice gratitude for, the greater ecology of which we are a part and parcel. Instead, our relationship to the worldmother is fundamentally split: with mother-nature as a bad object split-off from, and often numbed out by, the good object mother of high-tech culture. The possibility for fantasy life to be enriched by external reality-to be mediated by the internal and external wilds—is direly limited. Instead we remain stuck in a ruthless primitive object relationship of extractivism to get what we want now, leaving in our destructive wake something hollowed out, damaged, disintegrated, dead. The image of an open-pit-mine calls to mind a gaping maw, or open wound, or destroyed breast. Bertram Lewin (1946) wonders whether the mouth may not originally be felt in infantile fantasy as a wound healed through feeding. ${ }^{2}$ I would add, too, that the umbilicus is another mouth-like site in the skin, which becomes a wound that heals. These psychic images are mechanically "re-produced" in uncanny form ${ }^{3}$ through our perverse feeds (whether of mining, social media or otherwise), which are attempts to heal and whole ${ }^{4}$ (Melmed, 2019).

For the user of such technologies, this tremendous immediation of the internal and external wilds has had a dual and paradoxical effect of both gratifying and amplifying desire, expanding states of too much and not enough into staggering dimensions, while collapsing any psychic terrain between these states and diminishing our capacity to tolerate the frustration and anxieties generated by them. This occurs at individual and collective levels. With a constant onslaught of too much and not enough we are faced with what Bion (1962) calls a continuous negative realization, which overwhelms our capacity to transform the event of no breast into an experience (i.e., something psychically elaborated). And so a bottomless yearning opens that hyper-motivates a kind of compulsive pseudo-creativity to imagine and implement ways out of our dreadful dilemma through further forms of technologized immediation of experience. 
Thus the development and use of our technology in the modern era tends to be framed within an attitude of domination and subjugation, shot through with omnipotent and envious fantasy-a consequence of inadequate capacity to tolerate frustration (Bion, 1962). Harold Searles (1972) underscores how incapacity to tolerate loss provokes envious attacks: as our "technology-dominated world" alienates us from the possibility of living and dying "a truly human life" it impels us to pollute our world to guarantee we will have nothing to lose in our living or dying (p. 366-367). Wachtel (1991) puts it succinctly: "Our attitude toward nature and the environment has been much the same as our approach to each other; we strive for conquest and domination, not cooperative coexistence" (p. 100).

I think, too, of an omnipotent fantasy that operates in conjunction with the envious one, that all of technology comprises parts of a vast, universal, jury-rigged evacuative mechanism, not unrelated to Tausk's machine (1933), which will deliver us from death and extinction, promising us infinite progress and eternal life. A cult of immediacy has organized around this fantasy mechanism, its power felt through glimmers in every click, beep and glow of our technology. This fantasy machine is fueled by the false conviction that, as Bion (1962a) describes, evacuation or omnipotent modification of bad feeling and its perceived source is synonymous to sustaining and being sustained by a basic goodness. In reality this is not true. In lieu of the capacity for thinking omnipotent fantasy hypertrophies to compensate for the lack.

A vicious spiral ensues. As fantasy manifests incompletely in, and through our inventions, and the accumulations of material wealth we equate with good feeling, it further eggs on creative-imaginative tendencies in the service of wish-fulfillment. Imagination, then, might be considered a technology in and of itself, or a component in the machinery of desire. If we consider the imagination, as Michael Eigen (1999) does, a kind of infinity machine, then we can see how attitudes of too much and not enough can proliferate endlessly. Given our imaginations are less bound by place and time than our physical bodies, we are prone to jumping the fence of our corporeality and giving ourselves over to explorations of infinity. A consequence: omnipotent fantasies seduce us into action to materially create something more than we, and the world, can handle. Lack amplifies. Destructive tendencies take hold. As desire balloons beyond capacities, we are continually called on to heroically imagine and implement what amounts to quick fixes, the illusory deus ex machina of the day. Wachtel (1991) connects our chronic preoccupation with economic growth to this vicious circle: 
... plagued by an unquenchable thirst that does not let [us] rest [....] when our pursuit of material gain no longer brings much satisfaction and threatens to drown and choke us in industrial wastes, we are unable to let go-unable because we have cut the ground out from under us and are afraid to relinquish the things that prop us up, that give us some sense of security: our possessions and our productivity. (pp. 91-99)

William Blake (1790-1793), writing during the upsurge of the Industrial Revolution-at a time when the concept of enoughness was swelling to unimaginable proportions-proclaims that the road of excess leads to the palace of wisdom; that one doesn't know what enough is unless they know what is too much. In that way, enough IS too much. But one has to be able to know this, and in Bion's (1977) terms, to experience it, in order to make use of it. This is what Bion (1962b) calls learning from experience. And so it is, for us, in this day those faint protests of "Enough! Or Too much" (Blake, 1790-1793,) are swallowed up by ever widening chasms that demand "Not enough. More! " "How we decide what we "need," whether we are doing well or not well, whether we have enough or feel we are deprived or need more" is impaired (Wachtel, 2003, p. 104).

A consequence of this predicament is our climate crisis-often described as a 'runaway' process-the term capturing both the self-accelerating process over which we have limited control, and the extent to which we are running away from facing a phenomenon with profound implications and staggering complexities that we cannot bear to know. This double 'runaway' dynamic is pervasive, soaked into all aspects of modern life. As we currently find ourselves in the midst of a pandemic, scientists have begun to link rising global temperatures with an increased susceptibility to pathogens, which could result in greater frequency of future pandemics (Goudarzi, 2020). Not only is our ability to fight off infections adversely impacted by poor nutrition (Goudarzi, 2020), it is also affected by bad air quality (Younger et al., 2008). Both these conditions disproportionately afflict the poorest and most oppressed members of our species, a fact perhaps contributing to our country's significantly higher rates of serious illness and death from Covid-19 within communities of lower socio-economic status, indigenous peoples and people of color, and particularly Black Americans (CDC, 2020; Brandt et al., 2020). Climate change will exacerbate these conditions for the vast majority of people as food security and global supply chains deteriorate and air quality worsens (Goudarzi, 2020; Kinney, 2008). And some scientists predict that as global temperatures rise, resources dwindle, and habitable areas become scarcer, human contact will increase with other animals that could be potential vectors of unknown pathogens (Goudarzi). Joseph Dodds (2020) considers ways the pandemic is an 
"elemental catastrophe" (Freud, 1927, p. 16) that destabilizes the power structures, and attendant perceptual and affective schema, which reinforce our ecological crisis. Such catastrophes allow for the possibility of a reorientation of human life vis-à-vis the nonhuman world. The pandemic has foregrounded feelings of impotence and terror that our technologydominated, nature-alienated way of life has been so effective at blotting out. But it is uncertain to what extent this break-through of ecological realities will stimulate growth of needed capacities for the survival of our species, or have us doubling down on the destructive trends in our psyches fed by and feeding inner and outer catastrophes.

Goethe, a contemporary of Blake, gives expression in The Sorcerer's Apprentice (1797) to the ways a situation can quickly go awry when our technological powers and inadequate tolerance of frustration synergize with our grandiosity and destructive rage. The apprentice, miffed and wishing to make life easier, fashions an assembly line using wizardry he cannot wield. As his predicament gets out of hand, he attempts to seize control using one of humankind's most ancient technologies, the axe, to helplessly split his self-created monster, but this only accelerates his doom and compounds his rage. Our heroic efforts, with their undercurrent of annihilation-terror, can consciously or unconsciously, ignite and fuse with an axe-smashing rage, or, as is often the case, they can smolder as a nagging, often disowned sense of futility. ${ }^{6}$

You could say that human desire, understood as a thing that cannot be fulfilled, underwent significant development with the advent of technology. Or, perhaps our imagination qua technology has always served to compensate for and manage overwhelming feelings erupting from awareness of our finitude. Whether the cult of immediacy began with the dawning of human technology, or whether human technology is an extension, amplification, and dramatization of a broken desiring process to which we are still adapting, are open questions. Whatever the origin, the effect is an attitude that sees time and our living environment, the very medium of our lives, more as obstacles to living - needing to be objectified, debased, and bypassed - than as the function and fabric of life itself.

This attitude extends to our relationship to our bodies as well. Victor Tausk (1933, p. 555) writes in a footnote to his paper, "the machines produced by man's ingenuity and created in the image of man are unconscious projections of man's bodily structure. Man's ingenuity seems to be unable to free itself from its relation to the unconscious." Latent in this rich formulation is the idea, a delusional one, that man as a machine-maker is an omnipotent god, fashioning creations in his image, and with them influencing the world. There is truth in this. But Tausk points out that our technological ingenuity both liberates and burdens us. The omnipotent 
fantasy undergirding our relationship to machines ensnares us in a reactive creativity from which we are unable to free ourselves. These fantasies of greatness and power-constantly produced by and producing our technologies-ward off, repudiate, cover over, hallucinate away and deny the infantile anxieties engendered by psychic life. But the resulting nameless dread that threatens a sense of harmony and at-one-ment with the world continues to lurk in the shadows cast by our shiny new objects. Whether we like it or not, our creations and their toxic byproducts weigh on us: our climate crisis is proof.

So Tausk's formulation begs us to ask questions about the body, and how our technologies mediate our relationship to it. Let's take an example. The automobile extends and amplifies corporeal mobility. The image of Fred Flintstone driving exemplifies a combinatory primary process fantasy operating beneath our use of the automobile (which literally means "selfmoving".) The car both dissociates us from the body, and the tremendous damage cars can cause to it, and in turn it gives us the fantasy-feeling that our bodies are invincible and that we, as selves somehow independent of the body and merged with the machine, are super-powerful. The fused fantasy image masks dissociation. As mentioned, Winnicott (1945) highlights ways dissociation and destruction feed off each other. This is evident, too, in the cyborg of science fiction, which demonstrates the uncanny fantasy of machine and body melding together unleashing superpower and destructive potential. But this confusion handicaps: the cyborg exceeds limits, and is nevertheless painfully constrained, un-alive. Take another machine ubiquitous in our lives with which we are virtually fused. In what ways is a cellphone a projection of our bodily structure? ${ }^{7}$

If we are to consider bodily structure on the level of what Deleuze and Guattari (1987) call the body without organs, where boundaries form, dissolve, and reform in a continual flux, then we can begin to think of the cellphone in terms of gatherings and dispersions, impressions, expressions, and interruptions of flows of intensities. Combining this sensibility with Freud's (1923) notion that the self begins as a projection of bodily sensation, implying a sort of echo chamber buildup of resonances and dissonances, brought from the surface and extended into greater dimensionality, we arrive at a notion of an embodied self that extends well beyond the individual (Melmed, 2018, 2019; Melmed and Santiago, 2019).

This specular sensibility is also reflected in Merleau-Ponty's (1964) transpersonal concept of the flesh. With it we can understand the cellphone (which sounds like "self phone" and "self own") as both an extension and distortion of our specular relationship to our own body and the wider ecological body — of human and nonhuman selves—in which all experience is situated, and from which it emerges through the entwinement and 
dehiscence of the sensible sentient. But our cellphones tend more often than not to foreclose our fuller engagement with the world. As I've written elsewhere (Melmed, 2019), our technological wizardry:

... affords remarkable material convenience at the expense of maintaining, cultivating, and regularly honing our own indwelling magical sensory capacities. The ancient, vital, and exquisitely attuned sensory equipment that has functioned for eons to interlink us intimately with the human and more-thanhuman worlds and enabled us to participate as full actors in the multifaceted living, expressive environment (Abram, 1996), is appreciated now mostly as an instrument for generating capital. And so our underused and malnourished sensory faculties are something like the dilapidated, vacant, and vacating houses haunting many great metropolises. We are both slumlord and tenant of our experience; though it is especially difficult to discern this dilemma when blinded by the constant glow of our screens. (pp.107-108)

Another consequence is we lose touch with a primary aloneness (Eigen, 2008) that is midwife to a deeper communion with the living surround, and to a sense of support by, and devotion to, an unknown boundless other.

With this broader transhuman conceptualization of the body, we might consider our addictive relationship to technology as the symptom of a kind of psychosomatic illness writ large. Joyce McDougall (1982) talks about immediate and repetitive action short-circuiting the transformation of conflict-ridden external and internal realities to generative experience. Without the capacity for psychic digestion, unbearable affects must be evacuated, and projected into the flesh of our ecological body, from which we remain split-off. Fracking-wells, open-pit-mines, removed mountaintops, deforested landscapes: taking in these images re-evokes primitive agonies-for the images are ours to begin with. But the devastation, while real, does not fully register, for as McDougall reminds us, "psychosomatic symptoms... are primarily the result of avoidance mechanisms" (p.112). To view these images on your computer screen is of course vastly different than to stand in a deforested landscape while holding your laptop. No wifi. No battery. This is the predicament in which we find ourselves. So long as the reality of time and place - the matrix of the ecological body-is avoided we will be unable to experience, as a culture, our predicament. Searles (1972) writes:

the world is in such a state as to evoke our very earliest anxieties and at the same time to offer the delusional "promise," the actually deadly promise, of assuaging these anxieties, effacing them, by fully externalizing and reifying our most primitive conflicts that produce those anxieties. In the pull upon us to become 
omnipotently free of human conflict, we are in danger of bringing about our extinction. (p. 373)

\section{ADDENDUM}

Currently, in the days of the Covid-19 pandemic, psychotherapists and patients have become utterly reliant upon technologies of virtual care. While we have been barred from the usual intimacy of physical presence, and the safety and therapeutic potential it affords, we have also been permitted to enter virtually into each other's homes. And as many patients have become more immersed in domestic life than they were accustomed, it has exposed fault lines in their lives and revealed capacities that had otherwise been invisible or lain dormant. The construction of a new frame is underway with new permutations of fantasy and reality emerging for therapeutic work. For example, therapists and patients have had to grapple with de-idealizations of the therapist wrought by the pandemic. In shuttering our physical practices for the time being, and with much fumbling around with new technologies to connect with our patients, we signal our susceptibility to the same human anxieties and limitations that have troubled and brought them into our care. But shared fear, frustration and uncertainty can generate newfound intimacy that nourishes self-inquiry and psychic growth of patient and therapist alike. Many during this time are taking stock of emotional and physical geographies, re-mapping their worlds, resetting values about local life and the experiences drawn from the places they live, re-positioning themselves vis-à-vis others with an awakening sense of community.

The preceding paper has, in part, considered the influence of technology on our sense of time and place, and the influence of our experience of time and place, or lack there of, on our relationships to people, the nonhuman environment and to technology itself. The paper embraces conceptions of the body and psyche that extend beyond the individual and human, and explores how technology alters these conceptions. The provocative title of Philip K. Dick's (1968) novel Do Androids Dream of Electric Sheep? invites us to consider the ways dreaming, thought and imagination-the very stuff of psychoanalytic work-are troubled by technology. In the novel the distinction between human and machine is blurred: threatening androids appear indistinguishable from and walk undetected among people, and people are dependent on devices like "Mood Organs," "empathy boxes" and robotic pets to break through their dismal isolation and connect with something meaningful beyond their crumbling world. Now more than ever, with some of us even using devices called androids to connect with our 
patients, we can catch our reflection in the characters of Dick's novel. But the question remains of what happens to the peculiar form of human relatedness lived out in psychoanalytic practice, as it is mediated increasingly through the telephone and the screen, in disembodied forms against the backdrop of our global ecological crisis.

\section{ACKNOWLEDGMENT}

A version of this paper was published in French in Le Coq-Héron, Paris, Érès publications.

\section{NOTES}

1. Michael L. Melmed, Psy. D., is a clinical psychologist and Assistant Professor in the Department of Psychiatry at Columbia University where he works with traumatized toddlers, children and adults, and teaches and supervises clinicians engaged in this same work. He is a psychoanalytic candidate in the NYU Postdoctoral Program in Psychotherapy and Psychoanalysis. His areas of interest include the relationship between senseperception, imagination and trauma. He maintains a private practice in Lower Manhattan.

2. This oral-skin image may also be fused with that of the anus, another site for the evacuation and conveyance of bodily contents.

3. There is a temptation to ascribe yonic significances to the mine-image, which would include notions of reproduction and generativity, etc. (cf. J. Gentile, 2016). However, any such interpretation should be careful to consider the role of envious masculine fantasies that, in wishing to mimic generativity, seed greater destruction.

4. In English, the words heal and whole are cognates.

5. The allusion to defensive splitting (Klein, 1946) bears highlighting.

6. Goethe hugely influenced psychoanalytic thinkers with his conception of Nature. Georg Groddeck-whose It (taken up by Freud as the Id) was inspired by Goethe's powerful ideas on nature-"attacked violently what he called the 'scientification' and the 'rape of the divine' by psychoanalysis, and the appropriateness of the term 'bio-analysis,' when 'every analysis was always and always vainly concerned with Bios, Life"' (Grotjahn, 1945, p. 19). Another important early psychoanalyst, Sándor Ferenczi, "developed a relatively consistent theory and therapeutic practice, based on a number of philosophic and scientific assumptions of previous thinkers. In his imaginative speculations, he returned to the philosophy of nature of Goethe, Oken, Schopenhauer and German romanticism and adopted from them along with the old, Neo-Platonic idea that nature speaks to us ("natura loquitur") some of their mysticism as well (Hristeva, 2013, p. 349). [Emphasis added.]

7. I think we should also modify Tausk's formulation and consider the way our inventions are projections of our image of our bodily structure, an image which is formed by a culturebound sensibility that is woefully human-centric, atomistic and given to valuing hierarchical relatedness as the sin qua non of existence. 


\section{REFERENCES}

Abram, D. (1996). The spell of the sensuous: Perception and language in a morethan-human world (1st ed.). New York: Pantheon Books.

BBC Studios. (2008, April 4). Chimpanzees' sophisticated use of tools-BBC wildlife. [Video file]. Retrieved from https://www.youtube.com/watch?v=5Cp7_ $\ln 7$ f88\&t $=74 \mathrm{~s}$

Bion, W. R. (1962a). The psycho-analytic study of thinking. International Journal of Psycho-analysis, 43, 306-310.

Bion, W. R. (1962b). Learning from experience. London: Maresfield Library.

Bion, W. R. (1977). Seven servants: Four works. New York: Jason Aronson.

Blake, W. (1790-1793). The marriage of heaven and hell. New York: Dover. 1994.

Brandt, E. B., Beck, A. F., \& Mersha, T. B. (2020). Air pollution, racial disparities, and COVID-19 mortality. The Journal of Allergy and Clinical Immunology, 146(1), 61-63.

Centers for Disease Control and Prevention (CDC). (2020). Retrieved from https:// www.cdc.gov/coronavirus/2019-ncov/need-extra-precautions/racial-ethnicminorities.html.

Deleuze, G., \& Guattari, F. (1987). A thousand plateaus: Capitalism and schizophrenia. Minneapolis: University of Minnesota Press.

Dick, P. K. (1968). Do androids dream of electric sheep?. New York: Random House.

Dodds, J. (2020). Elemental catastrophe: Ecopsychoanalysis and the viral uncanny of COVID-19. Stillpoint Magazine, (4). Retrieved from https://stillpointmag.org/ articles/elemental-catastrophe-ecopsychoanalysis-and-the-viral-uncanny-ofcovid-19/.

Eigen, M. (1999). Toxic nourishment. London: Karnac Books.

Eigen, M. (2008). Primary aloneness. Psychoanalytic Perspectives, 5(2), 63-68.

Federici, S. (2018). Re-enchanting the world: Feminism and the politics of the commons. Oakland, CA: PM Press.

Freud, S. (1923). The ego and the id (Standard ed., pp. 1-161). London: Hogarth.

Freud, S. (1927). The future of an illusion (Standard ed., pp. 1-56). London: Hogarth.

Gentile, J. (2016). Feminine law: Freud, free speech, and the voice of desire. London: Karnac Books.

Ghent, E. (1990). Masochism, submission, surrender-Masochism as a perversion of surrender. Contemporary Psychoanalysis, 26, 108-136.

Goethe, J. W. (1797). The sorcerer's apprentice (E. Zeydel, Trans.). Richmond Virginia: Commonwealth University Press.

Goudarzi, S. (2020). How a warning climate could affect the spread of diseases similar to Covid-19. Scientific American, April 29, 2020. Retrieved from: https:// www.scientificamerican.com/article/how-a-warming-climate-could-affect-thespread-of-diseases-similar-to-covid-19/

Grotjahn, M. (1945). Georg Groddeck and his teachings about man's innate need for symbolization: A contribution to the history of early psychoanalytic psychosomatic medicine. Psychoanalytic Review, 32, 9-24.

Hristeva, G. (2013). Uterus Loquitur": Trauma and the human organism in Ferenczi's "Physiology of Pleasure. American Journal of Psychoanalysis, 73, 339-352.

Kinney, P. L. (2008). Climate change, air quality, and human health. American Journal of Preventive Medicine, 35(5), 459-467. 
Klein, M. (1946). Notes on some schizoid mechanisms. International Journal of Psycho-Analysis, 27, 99-110.

Lewin, B. D. (1946). Sleep, the mouth, and the dream screen. Psychoanalytic Quarterly, 15(4), 419-434.

McDougall, J. (1982). Theatres of the mind: Illusion and truth on the psychoanalytic stage (p. 2013). New York, NY: Taylor \& Francis.

Melmed, M. (2018). Repetition and difference: A proof of sorts. Free Associations, $74,101-102$.

Melmed, M. (2019). Fire, screens, and the cult of immediacy. The Candidate Journal, 8, 107-113.

Melmed, M. and Santiago, C. (2019). Blood magic in the age of psychopathy, mass shootings and ecological catastrophe. Manuscript submitted for publication.

Merleau-Ponty, M. (1964). The visible and the invisible. Evanston: Northwestern University Press. 1968.

Searles, H. F. (1972). Unconscious processes in relation to the environmental crisis. Psychoanalytic. Review, 59(3), 361-374.

Tausk, V. (1933). On the origin of the "influencing machine" in Schizophrenia. Psychoanalytic Quarterly, 2(3), 519-556.

Wachtel, P. L. (1991). The preoccupation with economic growth: An analysis informed by Horneyan theory. American Journal of Psychoanalysis, 51, 89-103.

Wachtel, P. L. (2003). Full pockets, empty lives: A psychoanalytic exploration of the contemporary culture of greed. American Journal of Psychoanalysis, 63, 103-122.

Winnicott, D. W. (1945). Primitive emotional development. International Journal of Psycho-Analysis, 26, 137-143.

Younger, M., Morrow-Almeida, H. R., Vindigni, S. M., \& Dannenberg, A. L. (2008). The built environment, climate change, and health: opportunities for co-benefits. American Journal of Preventive Medicine, 35(5), 517-526. https://doi.org/10. 1016/j.amepre.2008.08.017.

Publisher's Note Springer Nature remains neutral with regard to jurisdictional claims in published maps and institutional affiliations. 